\title{
GAMBARAN KADAR FOSFOR DARAH PADA LANJUT USIA 60-74 TAHUN
}

\author{
${ }^{1}$ Ni Komang Valentina \\ ${ }^{2}$ Youla A. Assa \\ ${ }^{2}$ Michaela E. Paruntu
}

\author{
${ }^{1}$ Kandidat Skripsi Fakultas Kedokteran Universitas Sam Ratulangi Manado \\ Bagian Biokimia Fakultas Kedokteran Universitas Sam Ratulangi Manado \\ Email: K.valentina11_107@yahoo.com
}

\begin{abstract}
Phosphorus is the second most abundant mineral in human body which counts for 1\% of weight. Eighty percents of phosphorus is found in bones and teeth, around $10 \%$ in blood and muscles, and $10 \%$ scattered in chemical compounds. Phosphorus is needed in bone and teeth classification, energy formation, absorption and transport of nutrients, acid-base balance, and as part of essential body tissues. This study aimed to obtain the phosphorus blood levels in elderly aged 60-74 years. This was a descriptive study with a cross-sectional design. Respondents were 26 people in Balai Penyantunan Lanjut Usia Senja Cerah (elderly housing) consisted of 11 males and 15 females. Blood samples were taken from vena without fasting. The phosphorus blood levels were examined by using molybdate UV method. The results showed that the mean blood phosphorus level was $3.4 \mathrm{mg} / \mathrm{dL}$. The blood phosphorus levels were normal in $88.4 \%$ of respondents, below normal levels $7.7 \%$, and above normal levels 3,8\%. Conclusion: Most of the elderly at Balai Penyantunan Lanjut Usia Senja Cerah aged 60-74 years had normal blood phosphorus level.
\end{abstract}

Keywords: Phosphorus blood level, ederly

\begin{abstract}
Abstrak: Fosfor merupakan mineral kedua terbanyak didalam tubuh, yaitu 1\% dari berat badan. Sebanyak $80 \%$ fosfor terdapat di dalam tulang dan gigi, sekitar $10 \%$ terdapat dalam darah dan otot, dan $10 \%$ tersebar luas dalam senyawa kimia. Fungsi fosfor antara lain dalam kalsifikasi tulang dan gigi, pembentukan energi, absorpsi dan transportasi zat gizi, keseimbangan asam-basa, dan sebagai bagian dari jaringan tubuh esensial. Penelitian ini bertujuan untuk mengetahui kadar fosfor darah pada lanjut usia 60-74 tahun. Penelitian ini bersifat deskriptif dengan desain potong lintang. Responden berjumlah 26 orang lanjut usia di Balai Penyantunan Lanjut Usia Senja Cerah yang terdiri dari 11 laki-laki dan 15 perempuan. Pemeriksaan kadar fosfor darah yang diambil melalui vena tanpa puasa dan diperiksa dengan menggunakan metode molybdate UV. Hasil penelitian menunjukkan rerata nilai kadar fosfor darah responden $3,4 \mathrm{mg} / \mathrm{dL}$. Hasil analisis menunjukkan kadar fosfor darah normal pada 88,4\% responden; di bawah normal 7,7\% responden; sedangkan di atas normal 3,8\% responden. Simpulan: Sebagian besar lanjut usia di Balai Penyantunan Lanjut Usia Senja Cerah usia 60-74 tahun memiliki kadar fosfor darah normal.
\end{abstract}

Kata kunci: fosfor darah, lanjut usia 
Salah satu tolok ukur kemajuan suatu bangsa dilihat dari harapan hidup penduduknya. Pada tahun 2014, penduduk di 11 negara anggota Word Health Organization (WHO) kawasan Asia Tenggara yang berusia diatas 60 tahun berjumlah 142 juta orang dan diperkirakan akan terus meningkat hingga tiga kali lipat pada tahun 2050. ${ }^{1}$ Indonesia merupakan salah satu negara berkembang yang harapan hidupnya diproyeksikan dapat mencapai lebih dari 70 tahun sebesar $11,34 \%$ pada tahun $2020 .^{2}$

Masalah kesehatan merupakan aspek yang sangat penting yang perlu diperhatikan oleh semua orang termasuk para lanjut usia. Salah satu indikator keberhasilan Pembangunan Kesehatan di Indonesia yaitu meningkatnya Umur Harapan Hidup (UHH) manusia Indonesia di mana pada Rencana Pembangunan Jangka Menengah (RPJMN) Depkes, tahun 2014 diharapkan terjadi peningkatan UHH dari 70,6 tahun pada 2010 menjadi 72 tahun pada 2014. Sejalan dengan meningkatnya usia harapan hidup maka akan terjadi perubahan struktur usia penduduk dengan bertambahnya jumlah penduduk lanjut usia. ${ }^{3}$

Fosfor yaitu mineral penyusun utama dari tulang dan gigi, yang memberikan kekuatan kepada jaringan. Seluruh sel-sel yang ada di dalam tubuh mengandung fosfor. Sekitar $66 \%$ fosfor di dalam tubuh terdapat pada tulang-tulang sebagai ikatan dengan garam kapur serta 33\% terdapat di dalam jaringan lunak sebagai ikatan organik dan anorganik. ${ }^{2}$

Kadar fosfor di dalam darah diatur oleh hormon paratiroid (PTH) yang dikeluarkan oleh kelenjar paratiroid dan oleh hormon kalsitonin. Selain hormon kalsitonin ada beberapa hormon lain yang membantu mengatur fosfat yaitu glukokortikoid, hormon tiroid, hormon pertumbuhan, insulin, dan estrogen juga dapat mempengaruhi pembentukan tulang dan metabolisme mineral. Efek utama glukokortikoid pada tulang merupakan penghambatan aktivitas osteoblastik meskipun aktivitas osteoblastik terganggu. ${ }^{4}$ Hormon PTH dan kalsitonin berinteraksi dengan vitamin $\mathrm{D}$ untuk mengontrol jumlah fosfor yang diserap, jumlah yang disimpan oleh ginjal, serta jumlah yang dibebaskan dan disimpan di dalam tulang. Hormon Paratiroid (PTH) menurunkan reabsorpsi fosfor oleh ginjal. ${ }^{5}$

Keseimbangan mineral merupakan kondisi ekuilibrium di mana jumlah mineral yang diserap dari makanan sama dengan jumlah semua mineral harian dari tubuh. Sekitar 99\% kalsium dalam tubuh ditemukan dalam kerangka, sehingga perubahan keseimbangan kalsium akan tercermin dalam perubahan massa tulang. Selama pertumbuhan, keseimbangan kalsium dan fosfat harus dipertahankan agar kebutuhan mineral dalam jumlah yang cukup untuk pertumbuhan tulang. ${ }^{4}$

Kekurangan fosfor serum (hipofosforinemia) dapat terjadi karena asupan yang tidak mencukupi, menggunakan obat antasida, atau kehilangan banyak cairan urin. ${ }^{6}$ Kelebihan fosfor (hiperfosforinemia) dapat ditemukan pada penderita jantung koroner dan gagal ginjal kronik yang telah menjalani hemodialisa rutin. ${ }^{7}$ Lanjut usia mempunyai risiko paling tinggi terkena osteoporosis. ${ }^{6}$ Dari laporan Perhimpunan Osteoporosis Indonesia, sebanyak 41,8 \% laki-laki dan 90\% perempuan sudah memiliki gejala osteoporosis, sedangkan 28,8\% laki-laki dan $32,3 \%$ perempuan sudah menderita osteoporosis.

Osteoporosis merupakan suatu masalah global di mana satu dari tiga wanita dan satu dari lima laki laki di atas usia 50 tahun di seluruh dunia mengalami fraktur karena osteoporosis. ${ }^{8}$ Prevalensi osteoporosis pada wanita sebesar 32\% sedangkan pada lakilaki 23,3\%. ${ }^{9}$ Kepadatan tulang lansia mulai berkurang sehingga berisiko mengalami osteoporosis. Selain itu, sistem gigi geligi menjadi tidak sempurna dan rapuh. ${ }^{8}$

\section{METODE PENELITIAN}

Penelitian ini menggunakan metode deskriptif dengan desain potong lintang. Lokasi penelitian bertempat di Balai Penyantunan Lanjut Usia (BPLU) Senja 
Cerah dan pemeriksaan sampel dilakukan di laboratorium Prodia. Variabel penelitian ialah kadar fosfor darah dan lanjut usia.

\section{HASIL PENELITIAN}

Berdasarkan jenis kelamin terdapat 11 responden laki-laki (42,3\%) dan 15 responden perempuan $(57,7 \%)$. Responden terbanyak pada usia 71 tahun yaitu 5 orang $(19,2 \%)$ dan yang paling sedikit pada usia 60, 61, 63, 64, 65, dan 67 tahun yaitu masing-masing 1 orang (3,8\%). Nilai kadar fosfor serum normal yaitu 2,7-4,5 mg/dL.

Hasil laboratorium menunjukkan rerata nilai kadar fosfor darah responden $3,4 \mathrm{mg} / \mathrm{dL}$, dengan nilai tengah yaitu 3,5 $\mathrm{mg} / \mathrm{dL}$. Nilai kadar fosfor pada penelitian ini yang paling sering muncul yaitu 3,6 $\mathrm{mg} / \mathrm{dL}$, sedangkan nilai maksimal sebesar 4,6 mg/dL dan nilai minimum sebesar 2,2 $\mathrm{mg} / \mathrm{dL}$ dengan nilai rentang sebesar 2,4 $\mathrm{mg} / \mathrm{dL}$. Dari hasil laboratorium kadar fosfor dapat dibagi menjadi 3 yaitu $<2,7$ $\mathrm{mg} / \mathrm{dL}$ pada 2 responden $(7,7 \%),>4,5$ mg/dL pada 1 responden (3,8\%), dan 2,7$4,5 \mathrm{mg} / \mathrm{dL}$ sebanyak 23 responden $(88,4 \%)$.

\section{BAHASAN}

Dari 26 responden, dapat dikelompokkan menjadi tiga bagian menurut kadar fosfor darah yaitu 23 responden $(88,4 \%)$ yang memiliki kadar fosfor darah normal (2,7-4,5 mg/dL); 2 responden $(7,7 \%)$ memiliki kadar fosfor darah di bawah normal $(<2,7 \mathrm{mg} / \mathrm{dL})$ yaitu hipofosforinemia; dan 1 responden (3,8\%) memiliki kadar fosfor darah di atas normal (>4,5 mg/dL) yaitu hiperfosforinemia. Aktivitas fisik yang cukup dan olah raga yang teratur mempengaruhi normal atau tidaknya kadar fosfor darah. Selain itu juga asupan fosfor yang memadai dapat mempengaruhi kadar fosfor darah. ${ }^{10}$

Sebanyak dua responden yang memiliki kadar fosfor darah di bawah normal (hipofosforinemia) kemungkinan dapat disebabkan oleh asupan yang tidak mencukupi, diare, penggunaan obat antasida, atau mengalami fosforuria. ${ }^{10}$ Defisiensi vitamin D atau karena gangguan absorpsi kalsium dapat meningkatkan hormon paratiroid, yang akan menghambat reabsorpsi fosfor dalam tubulus renalis. ${ }^{11}$ Juga disebabkan diet yang tinggi akan fosfor, misalnya diet tinggi protein atau banyak meminum minuman yang mengandung soda, dapat menurunkan kadar fosfor dalam tubuh. ${ }^{12}$

Jumlah fosfor yang lebih besar daripada kalsium akan menyebabkan berkurangnya massa tulang karena kelebihan fosfor dapat meningkatkan sekresi hormon paratiroid. Hormon paratiroid merupakan hormon yang mencegah terjadinya hipokalsemia dalam darah dengan cara meningkatkan pengambilan kalsium pada tulang sehingga dapat menyebabkan kepadatan mineral tulang menjadi berkurang. ${ }^{13}$

Hanya satu responden yang memiliki kadar fosfor darah di atas normal, dan penyebabnya belum diketahui. Penelitian oleh Pratama di RSUP Prof. Dr. R. D. Kandou Manado (tahun 2014), mendapatkan 18 orang (90\%) dengan hiperfosfatemia dari 20 orang pada penyakit ginjal kronik yang menjalani hemodialisis rutin. ${ }^{14}$

\section{SIMPULAN}

Dari hasil penelitian dapat disimpulkan bahwa sebagian besar lanjut usia di Balai Penyantunan Lanjut Usia Senja Cerah memiliki kadar fosfor darah normal.

\section{SARAN}

Disarankan agar responden yang memiliki kadar fosfor normal sebaiknya di pertahankan melalui diet seimbang dan melakukan aktivitas yang cukup. Bagi yang memiliki kadar fosfor tidak normal sebaiknya dilakukan pemeriksaan kadar fosfor darah dan melakukan konsultasi kesehatan kepada ahlinya.

Selain itu, perlu dilakukan penelitian dengan jumlah sampel yang lebih banyak dengan penambahan variabel penelitian, dan menghubungkan dengan kadar mineral yang lain, misalnya kadar kalsium dan vitamin D. 
DAFTAR PUSTAKA

1. Yulianti A, Baroya N, Ririanty $M$. Perbedaan kualitas hidup lansia yang tinggal di komunitas dengan di pelayanan sosial lanjut usia. Pustaka Kesehatan. 2014;2(1):87.

2. Matono H, Pranarka K. Geriatri. Jakarta: Balai penerbit FKUI, 2011; p. 345-65.

3. Workshop kesehatan lanjut usia. 2012 [cited 2014 Sep 20]. Available from: http://www.buk.kemkes.go.id/index.ph p?option=com_content\&view $=$ article\&i d=396: workshop-kesehatan-lanjut-usiamenuju-lansia-sehat-dan-aktif-melaluipendekatan-siklushidup\&catid=111: dasar\&Itemid $=136$

4. Wood RJ. Calcium and Phosphorus. In: Stipanuk M, editor. Biochemical, physiological, molecular aspects of human nutrition (2nd ed.). Philadelphia: Elsevier, 2006; p.888-915.

5. Almatsier S. Prinsip Dasar Ilmu Gizi. Jakarta: Gramedia, 2005; p. 243-6.

6. Chapter II.pdf. 2013 [cited 2014 Sep 20]. Available from: http://repository.usu.ac.id/bitstream/123 456789/28149/4/Chapter\%20II.pdf

7. Jordan KM, Cooper C. Epidemiology of osteoporosis. Best practice \& Research Clinical Rheumatology. 2002;16(5):795-805.

8. Permatasari D, Oktavianus, Wicaksono A. Hubungan aktivitas fisik dan terjadinya osteoporosis pada wanita pascamenopause di Poliklinik Bedah Tulang RSUD Dokter Soedarsono Pontianak. 2013;2(1):3.

9. Sennang AN, Mutmainnah, Pakasi RDN, Hardjoeno. Analisis kadar osteokalsin serum osteopenia dan osteoporosis. Indonesian Journal of Clinical Pathology and Medical Laboratory. 2006;2012(2):49-52.

10. Joewana S. Gangguan mental dan prilaku akibat penggunaan zat psikoaktif. Jakarta: ECG, 2005; p. 167.

11. Marjan AQ, Marliyati SA. Hubungan antara pola konsumsi pangan dan aktivitas fisik dengan kejadian osteoporosis pada lansia di pantai werdha Bogor. Jurnal Gizi dan Pangan. 2013;8(2):123-8.

12. Meikawati W. Hubungan kebiasaan mengkonsumsi makanan dan minuman berkarbonat dan berkafein dengan kepadatan tulang remaja. Kesehatan masyarakat Indonesia. 2008;4(2):90-1.

13. Dewayani R. Penyakit jantung koroner pada chronic kidney disease. Kardiologi Indonesia. 2007;28(5):392.

14. Pratama A, Moeis E, Mandang V. Hubungan produk Ca x P dengan kadar C-terminal cross linking telopeptide type I collagen pada subjek penyakit ginjal kronik yang menjalani hemodialisa rutin. e-Clinic. 2014;2(3):4-6. 